\title{
Investigating Outdoor Thermal Comfort of Educational Building Complex in Urban Area: A Case Study in Universitas Kebangsaan, Bandung City
}

\author{
Try Ramadhan ${ }^{\mathrm{A}^{*}}$, Aldissain Jurizat ${ }^{\mathrm{A}}$, Andina Syafrina ${ }^{\mathrm{B}}$, Amat Rahmat ${ }^{\mathrm{C}}$ \\ Received: January 20, 2021 | Revised: April 09, 2021 | Accepted: May 03, 2021 \\ doi: $10.5937 / g p 25-30430$
}

\begin{abstract}
Campus building was a place to accommodate various educational activities, which were both carried out indoors and outdoors. The environment, including the building and its exterior, provided thermal comfort that was influenced by the context, such as the mass of the facility, vegetation, and constructing envelope materials. The microclimate also influenced the environment, such as temperature, wind speed, and humidity. This study aimed to investigate the outdoor thermal comfort of campus building in urban area during summer, while also identifying the influential factors. This research referred to a case study, examining the thermal quality of the educational building environment using ENVI-met software, based on the Predicted Mean Vote (PMV) index as an indicator of outdoor thermal comfort, in Universitas Kebangsaan (UK). The results showed that the outdoor environment had low thermal comfort conditions during the day, as it also had different thermal satisfactory situations, due to differences in physical characteristics in each zone. This characteristics included, (1) The SVF determinant as indicators of the shading factor should be supported by the presence of vegetation and the use of pavement material, (2) Although the wind speed factor does not really affect the thermal comfort in the outdoor space, the interconnection between open gaps is likely to make breeze distribution in the area better. This study offered direction for campus planning, in order to maintain the optimal capacity of the natural environment, such as (1) Strategizing to create a better shadowing factor in the outer space, which was supported by controlling the use of pavement materials, (2) Directing the density of buildings by making open spaces more permeable, in order for better wind distribution in the area. From this study, the campus current conditions and future design development potential was also observed.
\end{abstract}

Keywords: Outdoor thermal comfort; Educational building; Urban area; Micro climate; PMV

\section{Introduction}

Outdoor thermal conditions in the campus area, significantly impact students' comfort in carrying out their activities (Huang et al., 2019). Student academic activities are carried out both indoors and out- doors, especially for individual or group study. Moreover, campus as an educational facility should provide a good outdoor environment, in order to support the students' activities.

\footnotetext{
A Universitas Pendidikan Indonesia, Bandung, West Java, Indonesia, tryramadhan@upi.edu; aldissain@upi.edu

B Institut Teknologi Bandung, Bandung, West Java, Indonesia, andina.syafrina@gmail.com

C Universitas Kebangsaan, Bandung, West Java, Indonesia,amatrahmat.saja@gmail.com

* Corresponding Author: Try Ramadhan, e-mail: tryramadhan@upi.edu; Tel: +62 82184828861
} 
The outdoor thermal comfort is influenced by regional climate and urban conditions. These factors produce four variables affecting the thermal comfort of the human body, including air and mean radiant temperatures, humidity, and wind velocity (Zomorodianet al., 2016). The outdoor environment also contains circulations, open spaces, and other physical elements, as the opened gap is usually designed as a green park or sports facility. In many universities, campus buildings with an outdoor environment, such as a green park and sports facility, are often observed.

Also, thermal comfort was separated from climate factors. Designing buildings and outdoor environments by considering climatic factors not only provide comfortable thermal conditions, it also increase satisfaction and improve human health (Ghaffarianhoseini et al., 2019). Apart from external factors, internal indicators also affect thermal comfort. These factors are in the form of clothes used and activities carried out (Fanger, 1970). Besides these two factors, design elements also affected, such as artificial surface materials, paving, concrete, asphalt, with buildings and vegetation (Jeong et al., 2015).

Campus buildings are usually located in urban areas, which causes discomfort vulnerability, due to the microclimate. In the parametric studies carried out by Bajsanski et al. (2019), the urban microclimate was improved and more comfortable, through different street orientations, vegetation, and building geometries. Mitigation of thermal overheating in an urban context, including campus building, is very important in obtaining better conditions for human well-being. Therefore, several studies have also been conducted to see the potential for urban environment mitigation.

Thermal comfort research in the campus area had started to be carried out, for example, the study of outdoor conditions on campuses, in summer and winter climates (Huang et al., 2019). Also, previous studies had been conducted in subtropical urban areas, which focused on the influence of various design element types (Xi et al., 2012). Furthermore, wind environment as an essential aspect of urban micro-climate was also studied in two schools in Nanjing, which focused on schoolyard wind environments, from the standpoint of children and teenagers (Liu et al., 2019). Various micro-climatic factors, such as seasons, various types of design elements, wind, vegetation, and more, are needed to be considered in the case of ed- ucational buildings, within an urban context. Recent research in Kuala Lumpur, also tried to study the thermal characteristics in a university campus, in the tropical climate. This study used the ENVI-met simulation, and discovered that there were significant impacts of shading and vegetation, on increased thermal comfort (Ghaffarianhoseini et al., 2019). ENVI-met simulations had also been used to devise solutions, in order to reduce heat stress, and create student thermal comfort in open spaces, between education buildings. This study used PMV as a parameter to assess its thermal comfort (Abdallah et al., 2020).

ENVI-met is one of the most commonly used software tools, which aids in understanding the impact of architectural and urban designs, on outdoor thermal comfort (Salata et al., 2016). This software simulates the interactions between the urban design and the microclimate, in order to calculate human comfort. It also generates output containing the thermal comfort parameters, including external and internal input terms (Taleghani et al., 2015). Also, this software is often used in analyzing thermal comfort in educational building cases.

Moreover, Universitas Kebangsaan is one of the educational building complexes in Bandung, Indonesia. This campus is located in the urban area of Bandung, as it preserves the original campus design from 1992. After being established for a long time, Universitas Kebangsaan has plans to physically develop its campus. There are increasing demands from the number of students that needs to be accommodated, as the limited site ownership makes this campus optimize the existing land. This future campus development should be able to create a better quality outdoor environment, in order to accommodate student activities.

This study aims to explore the thermal characteristics of various outdoor areas of the campus building, which is located in an urban environment. Also, this research tries to identify the important parameters, which affects outdoor thermal comfort. Additionally, this study should also suggest some future design considerations, based on the parameters observed. The research is conducted using the ENVI-met simulation, as the benefits of this study should provide input for future campus developments. Broadly, this study also contributes to the development of knowledge, which is related to the outdoor thermal comfort conditions in types of educational building complexes, especially in tropical climates, such as Bandung City.

\section{Data and Methods}

Based on phenomena occurrences, this research used a quantitative descriptive-comparative approach, which explained data in the form of numbers. This study also referred to a case study, by examining the thermal quality of the educational building environment using ENVI-met software, based on the Predict- 
ed Mean Vote (PMV) index. PMV was used as a parameter of thermal comfort in this study. Based on ISO 7730, PMV is an index that predicted the average value of human groups against 7 thermal sensation scales, based on the heat balance of the body (International Organization for Standardization, 2005). The seven thermal sensation scales consisted of +3 hot, +2 warm, +1 slightly warm, 0 neutral, -1 slightly cool, -2 cool, and -3 cold. Generally, neutral was a condition of comfort that needs to be achieved in the thermal comfort of an environment, for humans (Olesen \& Parsons, 2002). This research used the seven thermal sensation scales, which were accumulated from the climatic conditions at the research area. JMP software analysis was also carried out, in order to compare the simulation results.

This research had the following stages :

1. A literature review was carried out, in order to build a repertoire of knowledge related to climate, thermal comfort and its standards, educational buildings, and recent research;

2. Modelling case studies from primary data obtained;

3. Inserting climate conditions data in Envi-Met software, and carrying out the simulation;

4. Analyzing and interpreting the simulation results descriptively and comparatively;

5. Carrying out a more in-depth investigation, based on the different characteristics of the outdoor area in the case studies;

6. Drawing conclusions.

\section{Data and Sources}

The data used were both primary and secondary. Primary data were directly related to case studies, such as measurements of size, orientation, vegetation, building materials, and the environment. This type of data collection was carried out by direct observation of the case study area. Secondary data used were also in the form of macroclimate information, which were obtained from the meteoblue web and literature. These two main data were both used to obtain thermal comfort, with both external and internal factor data.

\section{External factor data}

The external factor data were related to climate, and obtained from the meteoblue web. This site provided global climate data, which were collected from a span of 30 years, with hourly weather information. Meteoblue weather models were based on the NMM (Nonhydrostatic Meso-Scale Modeling) technology, which specifically described the weather in an area, such as temperature, wind speed, and clouds (Meteoblue, 2020). The drawback of this data was the fact that it was unable to reproduce details of local weather effects, such as hot islands, cold air currents, thunderstorms, or tornadoes. Even at that, this data was sufficiently a representative of the climatic conditions in the case study locations studied. The climate data as an external factor, was very useful in predicting the level of thermal comfort (Sujatmiko et al., 2019).

The main reason for using this data was the long collection period, as it represented the climate of an area. The research had also compared the climate data with those held by the official weather station, which belonged to the Meteorology, Climatology, and Geophysics Agency (BMKG), Bandung. The results of the comparison further showed a close suitability, as the meteoblue web data was still used in this study. Specific climate sample data were also obtained in the case area, in order to ensure accuracy.
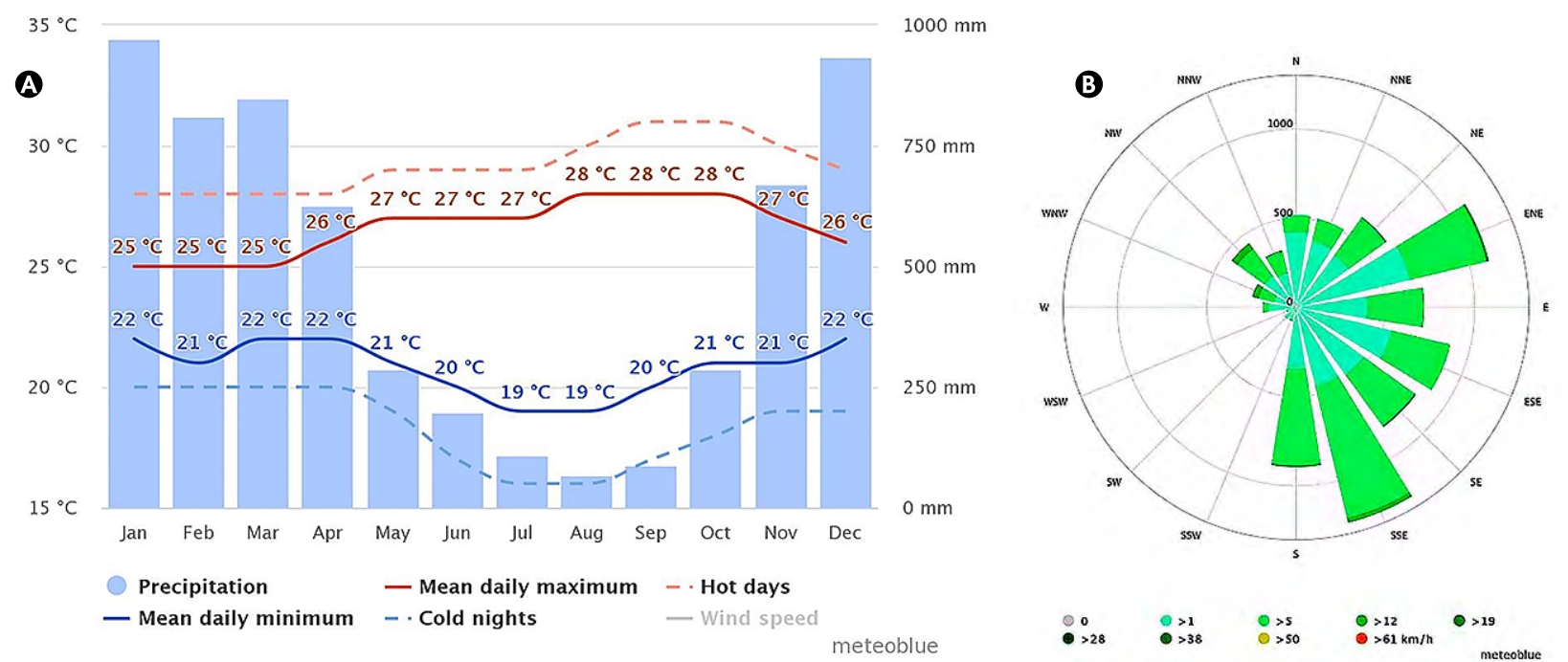

Figure 1. (A) Temperature and precipitation; (B) Wind rose Source : meteoblue.com (Meteoblue, 2020) 
Climatic data were obtained at a specific area, at $6.93^{\circ} \mathrm{S} \& 107.63^{\circ} \mathrm{E}$. External data were also collected on extreme climatic conditions, within a year. The extreme conditions were considered to provide a picture of the thermal conditions, which needed more concern, with the selected month being September. There were also extreme high and low temperature limits at 31 ${ }^{\circ} \mathrm{C}$ and $17^{\circ} \mathrm{C}$, within the month (confirmed in BMKG data), respectively (see Figure 1a) (Badan Meteorologi Klimatologi Geologi, 2020). Therefore, this temperature range was used as input. Regarding the wind, it was obtained from the Southeast, with a speed and altitude of $2.2 \mathrm{~m} / \mathrm{s}$ and $10 \mathrm{~m}$, respectively (see Figure $1 \mathrm{~b}$ ).
The extreme conditions in September were also observed in the sun path diagram. The position of the sun was directly above the equator (Equinox), causing the air temperature to rise (see Figure 2.a). This phenomenonalso caused radiation emission received at the area, which was the highest in a year. The duration of exposure due to the angle of the sun, also reached the maximum level(see Figure 2.b).

Meteorological data obtained was on September 14, 2020. Based on the meteoblue data, the information collection day had the highest peak temperature with humidity, which seemed to vary.The most dominant wind came in from $104-137^{\circ}$ direction, as the South-

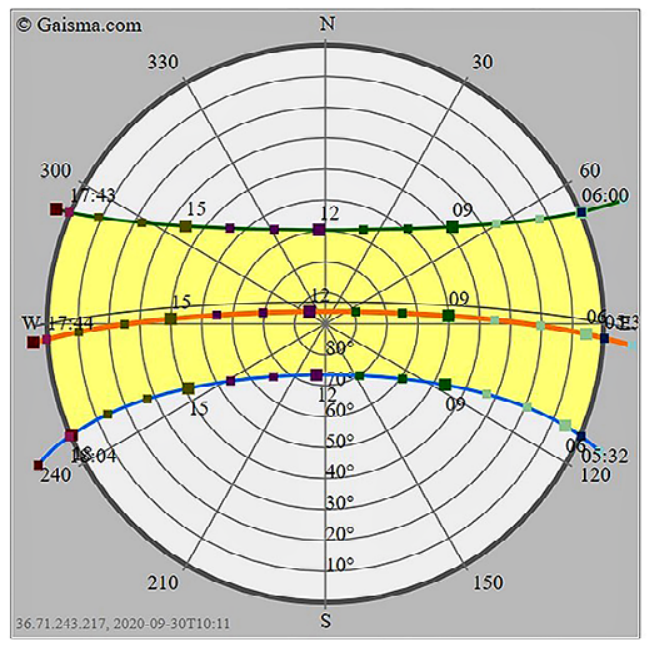

Sun path

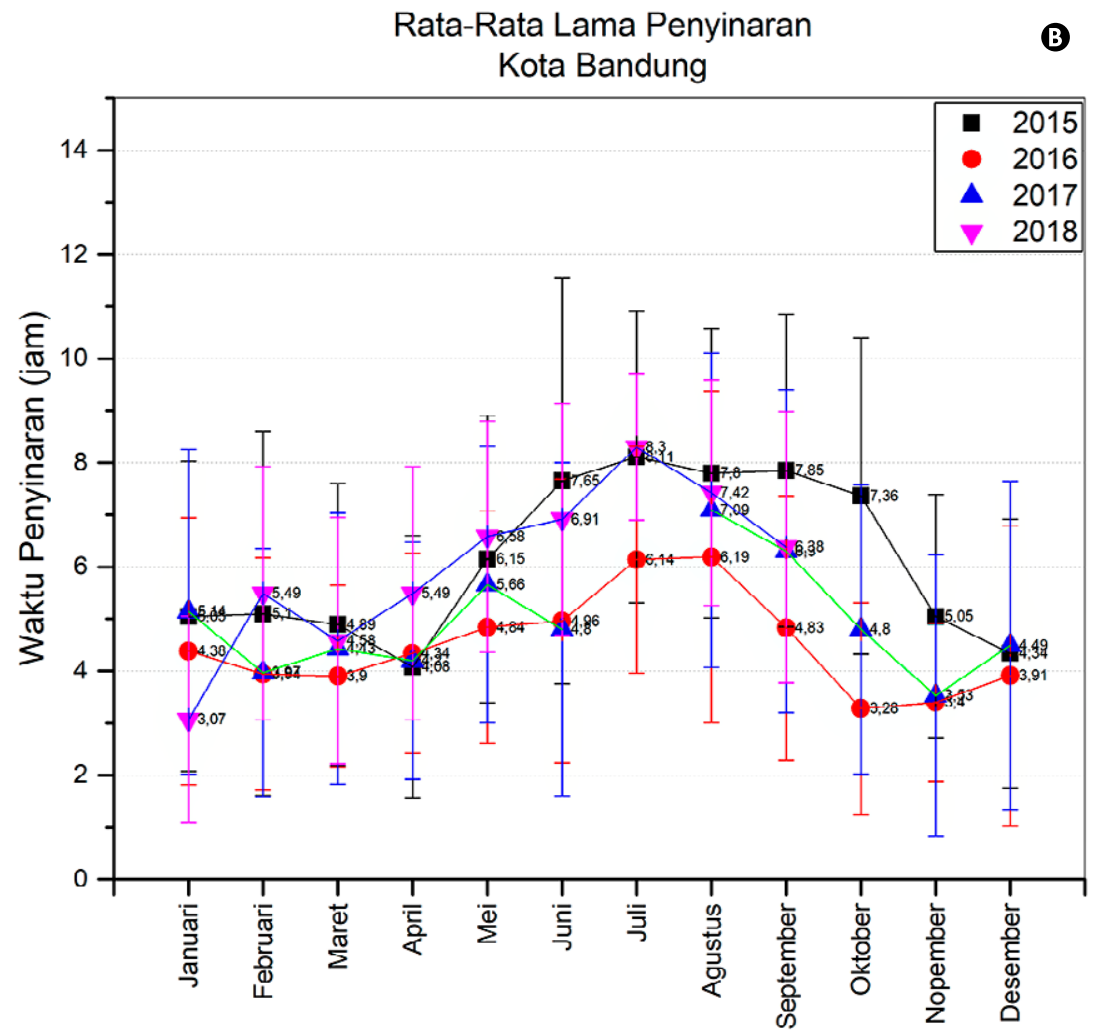

Figure 2. (a) Sun path diagram and (b) sunshine of Bandung Source: (a) Gaisma (2020) and (b) Kusyanto et al. (2019) 
east direction was obtained as the simulation input (see Table 1). This information had also been confirmed by using Meteorological, Climatological, and Geophysical Agency (BMKG) data. The difference in the mean temperature data was only $0.1{ }^{\circ} \mathrm{C}$ lower, compared to the BMKG data.

Table 1. Meteorological data

\begin{tabular}{|l|c|c|c|c|}
\hline Time & $\mathrm{T}\left({ }^{\circ} \mathrm{C}\right)$ & $\mathrm{Rh}(\%)$ & $\mathrm{V}(\mathrm{m} / \mathrm{s})$ & $\begin{array}{c}\text { Wind Direction } \\
\left({ }^{\circ}\right)\end{array}$ \\
\hline 12:00 AM & 19.24 & 71 & 2.27 & 131.42 \\
\hline 1:00 AM & 18.74 & 72 & 2.44 & 124.99 \\
\hline 2:00 AM & 18.01 & 74 & 2.61 & 122.47 \\
\hline 3:00 AM & 17.64 & 75 & 2.69 & 121.33 \\
\hline 4:00 AM & 18.04 & 74 & 3.26 & 117.35 \\
\hline 5:00 AM & 17.92 & 74 & 3.42 & 110.56 \\
\hline 6:00 AM & 16.79 & 78 & 3.01 & 111.45 \\
\hline 7:00 AM & 16.51 & 80 & 2.88 & 110.32 \\
\hline 8:00 AM & 18.56 & 75 & 2.97 & 109.65 \\
\hline 9:00 AM & 21.08 & 70 & 2.62 & 107.74 \\
\hline 10:00 AM & 23.45 & 63 & 1.65 & 104.04 \\
\hline 11:00 AM & 25.28 & 58 & 0.51 & 78.69 \\
\hline 12:00 PM & 27.00 & 52 & 0.54 & 338.20 \\
\hline 1:00 PM & 28.57 & 48 & 0.85 & 69.44 \\
\hline 2:00 PM & 29.53 & 44 & 0.30 & 360.00 \\
\hline 3:00 PM & 30.00 & 42 & 0.42 & 315.00 \\
\hline 4:00 PM & 30.07 & 42 & 0.36 & 326.31 \\
\hline 5:00 PM & 29.84 & 43 & 0.00 & 180.00 \\
\hline 6:00 PM & 29.20 & 46 & 0.58 & 120.96 \\
\hline 7:00 PM & 28.44 & 47 & 1.25 & 118.61 \\
\hline 8:00 PM & 27.49 & 52 & 2.08 & 125.22 \\
\hline 9:00 PM & 25.35 & 61 & 2.26 & 135.00 \\
\hline 10:00 PM & 24.11 & 64 & 1.77 & 137.29 \\
\hline 11:00 PM & 23.13 & 68 & 1.63 & 137.49 \\
\hline & & & & \\
\hline
\end{tabular}

Reference: meteoblue.com (Meteoblue, 2020)

\section{Internal factor data}

This study also used data from internal factors, such as the personal characteristics of students' parameters, which became the subject of the research. The characteristics that needed to be included in the BIO-met software on ENVI-met, were age, sex, height, weight, clothing level, and metabolic rate (see Table 2). As the subject of this research, the characteristics selection were also obtained from the reference of students, including,

Table 2. Internal factor input

\begin{tabular}{|l|l|}
\hline Data Input & 21 years old \\
\hline Age & Male \\
\hline Sex & $164.3 \mathrm{~cm}$ \\
\hline Height & $58.8 \mathrm{~kg}$ \\
\hline Weight & Student \\
\hline Occupation & $0.75 \mathrm{clo}$ \\
\hline Clothing & Standing $69.84 \mathrm{~W} \cdot \mathrm{m}^{-2}(1.2$ met level $)$ \\
\hline Activity / Metabolic Rate
\end{tabular}

1. Age: The age parameter used in this study was 21 years. This choice was due to the average age of students within the range of $18-25$ years (Hulukati \& Djibran, 2018).

2. Sex: The sex parameter also used in this study was the male gender. The actual thermal response tended to vary by gender, with this difference tending to decrease under the conditions of increased ambient temperature, and clothing insulation (Yin et al., 2020). Under certain conditions, the thermal sensation of women was lower, compared to men, resulting in this study usingmaleparameters (Wang et al., 2019).

3. Height and weight: The parameters of height and body weight obtained were $164.2 \mathrm{~cm}$ and $58.8 \mathrm{~kg}$, respectively. They were selected based on the average weight and height, according to the age and sex groups (Muljati et al., 2016).

4. Clothing insulation level: The clothing level parameteralso used was $0.75 \mathrm{clo}$. This value was obtained, based on the assumption of clothes commonly used by students in Indonesia. The values were a combination of men's briefs (0.04), t-shirt $(0.08)$, shoes (0.02), calf-length socks (0.03), longsleeve flannel wear (0.34), and straight trousersthick (0.24) (Parkinson \& de Dear, 2017).

5. Metabolic rate: Also, the metabolic rate parameter used was $69.84 \mathrm{~W} \cdot \mathrm{m}^{-2}$ (1.2 met level). This value represented standing activity (Gonzalez, 1995), which was used as the minimum basic event. The assumption that there were other student activities, such as sports or other events, were interpreted to be higher than the minimum score.

\section{Case Study}

The research location was at the Universitas Kebangsaan in Bandung. The university is a development college from the Institut Teknologi Adityawarman (ITA), which was established on August 15, 1985. It had its own campus in the academic year 1992-1993, which is located at Terusan Halimun Street 37 (Pelajar Pejuang 45) Bandung, West Java, Indonesia (see Figure 3). Also, the campus building was located in the downtown area of Bandung, as it had been 28 years since its establishment. 

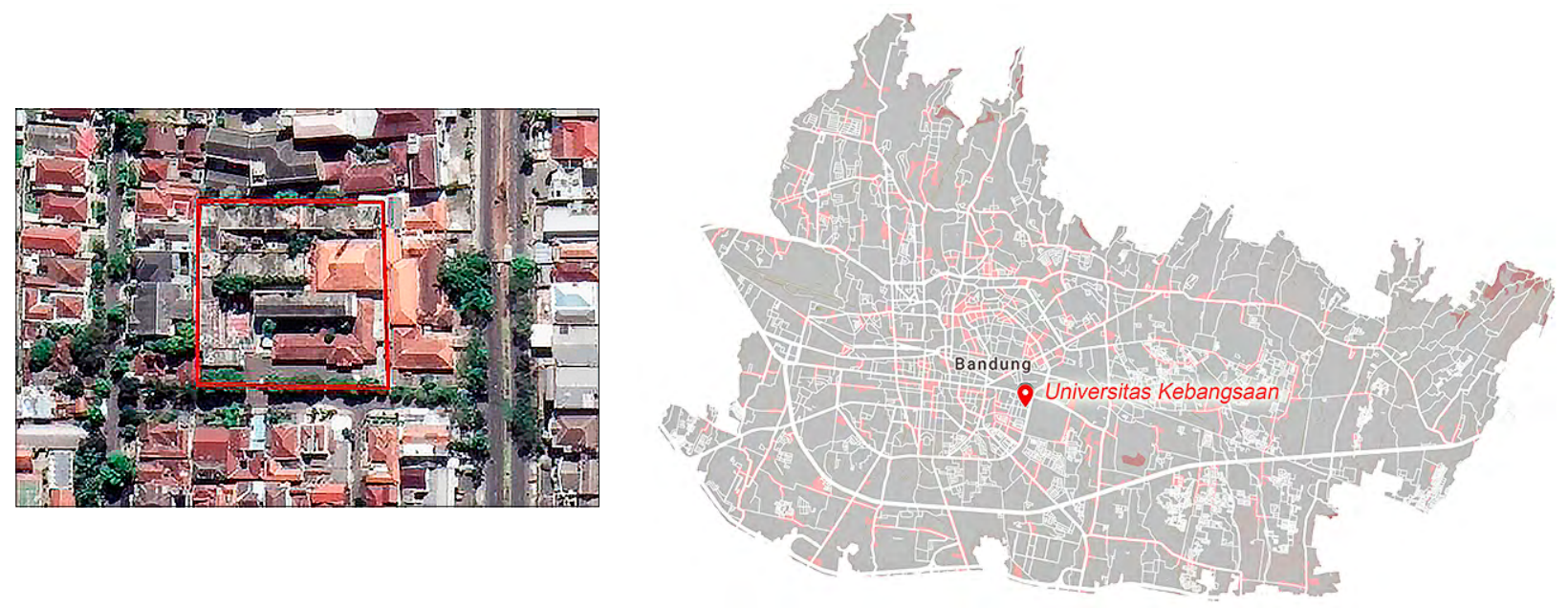

Figure 3. Location of case study in urban context of Bandung

One of the important premises of 2018-2028 their strategic plan, was to achieve academic excellence and distribution at every level of the structure, by integration through physical campus development. Campus development was also directed to become a "city campus", which had facilities and infrastructures in national and international competitions that were likely to still uphold the environment, religion, technology, socio-culture, and sustainability in the future. With this developmental plan, it was very important to evaluate the existing condition of the building, as input for future development.

\section{Outdoor zone division}

Due to the different characteristics of the outdoor area on this campus, the division of the external zone was necessary. This zoning was needed, in order to observe the specificity of the thermal comfort quality, from different areas. This division also facilitated the presentation and explanation of the data. Additionally, this division was also considered, based on differences in functions or specific characters in Table 3.

The outdoor zone was further divided into six, namely corridor 1, 2, 3 (COR1, COR2, COR3), canteen $(\mathrm{CAN})$, court (COU), and parking (PAR) areas. The six
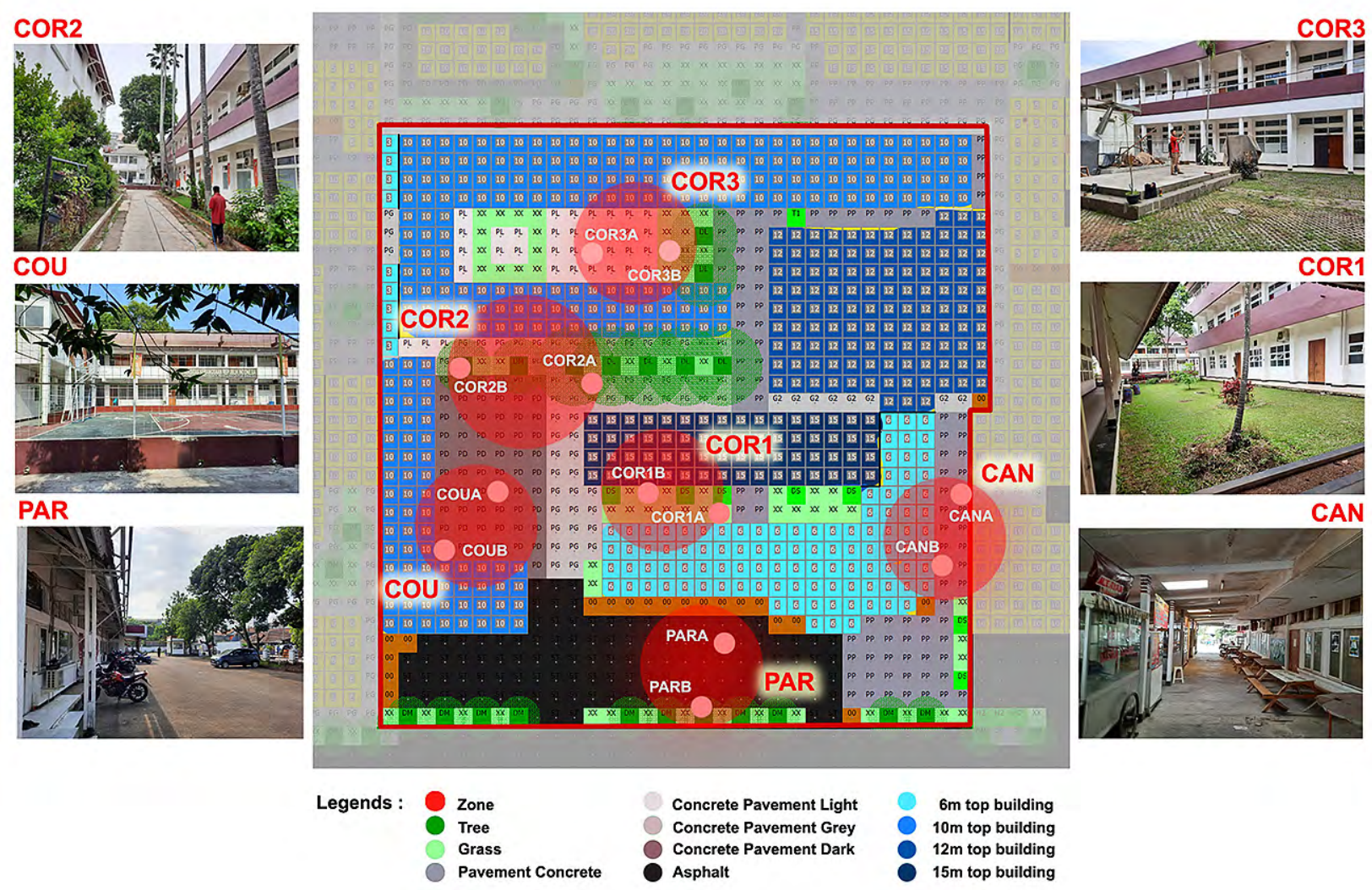

Figure 4. The outdoor zone division in the case study 
sub-zones were divided, based on differences in physical characteristics, including location within the area, building orientation, vegetation ratio, surface materi$\mathrm{al}$, and construction geometry adjacent to the outdoor zone (Figure 4 and Table 3). In Figure 4, these characteristics were shown in details, as the difference in building height, surface material, and vegetation area representing the division of the zones, were observed.

Furthermore, the six zones were further divided into 12 points. The division of the 12 sub-zones was carried out, due to each zone still having differences (Figure 4 and Table 3). This zonal divisions were expected to provide an in-depth description of each different character, in the campus outdoor environment. Further in the study, discussion and analysis were referred to this zoning.

The average thermal condition in the six different zonal division, provided an initial description of this study. In Table 4, it was observed that the average air and radiant temperatures, humidity, wind velocity,

Table 3. The outdoor zone division is based on different characteristics.

\begin{tabular}{|c|c|c|c|c|c|c|c|c|c|}
\hline Zone & Sub Zone & Description & $\begin{array}{l}\text { Building } \\
\text { Orientation }\end{array}$ & $\begin{array}{c}\text { Direct } \\
\text { Radiation } \\
\text { (time) }\end{array}$ & SVF & $\begin{array}{c}\text { GnPR } \\
(\%)\end{array}$ & $\begin{array}{l}\text { PLC } \\
(\%)\end{array}$ & PLCM & Spesific Characteristic \\
\hline \multirow[t]{2}{*}{ COR1 } & COR 1A & Corridor $1 \mathrm{~A}$ & North - South & $10-16$ & 0.2 & $37 \%$ & $5 \%$ & $\begin{array}{l}\text { Grass and } \\
\text { pavement }\end{array}$ & Corridor \\
\hline & COR 1B & Corridor 1B & North - South & $13-16$ & 0.3 & $35 \%$ & $0 \%$ & Grass & Corridor \\
\hline \multirow{2}{*}{ COR2 } & COR 2A & Corridor 2A & North - South & $08-13$ & 0.3 & $27 \%$ & $21 \%$ & $\begin{array}{c}\text { Grass- Concrete } \\
\text { Pavement }\end{array}$ & $\begin{array}{l}\text { Under the tree and } \\
\text { between building }\end{array}$ \\
\hline & COR 2B & Corridor 2B & North - South & None & 0.1 & $45 \%$ & $23 \%$ & $\begin{array}{c}\text { Concrete } \\
\text { Pavement Light }\end{array}$ & $\begin{array}{l}\text { Under the tree and near } \\
\text { from building }\end{array}$ \\
\hline \multirow[b]{2}{*}{ COR3 } & COR 3A & Corridor $3 \mathrm{~A}$ & North - South & $09-16$ & 0.3 & $0 \%$ & $25 \%$ & $\begin{array}{c}\text { Concrete } \\
\text { Pavement Light }\end{array}$ & $\begin{array}{l}\text { In the middle of court } \\
\text { and between building }\end{array}$ \\
\hline & COR 3B & Corridor 3B & North - South & $13-16$ & 0.2 & $29 \%$ & $6 \%$ & $\begin{array}{c}\text { Grass and } \\
\text { Concrete } \\
\text { Pavement Light }\end{array}$ & $\begin{array}{l}\text { Between building and } \\
\text { under the tree }\end{array}$ \\
\hline \multirow{2}{*}{ CAN } & CAN A & Canteen A & East - West & $11-14$ & 0.30 & $0 \%$ & $25 \%$ & $\begin{array}{l}\text { Concrete } \\
\text { Pavement }\end{array}$ & $\begin{array}{l}\text { Between building (In the } \\
\text { middle of canteen) }\end{array}$ \\
\hline & CAN B & Canteen B & East - West & $10-12$ & 0.20 & $1 \%$ & $24 \%$ & $\begin{array}{l}\text { Concrete } \\
\text { Pavement }\end{array}$ & $\begin{array}{c}\text { Circulation in between } \\
\text { building }\end{array}$ \\
\hline \multirow[t]{2}{*}{$\mathrm{COU}$} & COUA & Court A & East - West & $09-15$ & 0.5 & $0 \%$ & $25 \%$ & Concrete & $\begin{array}{l}\text { In the middle of } \\
\text { basketball court }\end{array}$ \\
\hline & COUB & Court B & East - West & $08-12$ & 0.2 & $0 \%$ & $25 \%$ & Concrete & Near building \\
\hline \multirow[t]{2}{*}{ PAR } & PARA & Parking A & East - West & $08-16$ & 0.5 & $0 \%$ & $25 \%$ & Asphalt & $\begin{array}{c}\text { In the middle of parking } \\
\text { area }\end{array}$ \\
\hline & PARB & Parking B & East - West & None & 0.3 & $25 \%$ & $13 \%$ & Asphalt & Under the Tree \\
\hline \multicolumn{2}{|l|}{ SVF } & \multicolumn{8}{|c|}{ Sky View Factor } \\
\hline \multicolumn{2}{|l|}{ GnPR } & \multicolumn{8}{|c|}{ Green Plot Ratio } \\
\hline \multicolumn{2}{|l|}{ PLC } & \multicolumn{8}{|c|}{ Pavement Land Cover } \\
\hline \multicolumn{2}{|l|}{ PLCM } & \multicolumn{8}{|c|}{ Pavement Land Cover Material } \\
\hline
\end{tabular}

Reference: author's own work

Table 4. The average thermal condition in different zone division

\begin{tabular}{|c|c|c|c|c|c|c|}
\hline \multirow{2}{*}{ Zone } & \multirow{2}{*}{ Sub Zone } & \multicolumn{5}{|c|}{ The average of thermal conditions ( $6 \mathrm{am}-5 \mathrm{pm})$} \\
\hline & & Air Temperature $\left({ }^{\circ} \mathrm{C}\right)$ & Humidity (\%) & Wind Velocity $(\mathrm{m} / \mathrm{s})$ & Mean Radiant Temperature $\left({ }^{\circ} \mathrm{C}\right)$ & PMV \\
\hline \multirow{2}{*}{ COR1 } & COR $1 \mathrm{~A}$ & $24^{\circ} \mathrm{C}$ & $59 \%$ & $0,9 \mathrm{~m} / \mathrm{s}$ & $41^{\circ} \mathrm{C}$ & 1,2 \\
\hline & COR 1B & $24^{\circ} \mathrm{C}$ & $60 \%$ & $1,1 \mathrm{~m} / \mathrm{s}$ & $36^{\circ} \mathrm{C}$ & 0,8 \\
\hline \multirow{2}{*}{ COR2 } & $\operatorname{COR} 2 \mathrm{~A}$ & $24^{\circ} \mathrm{C}$ & $58 \%$ & $0,37 \mathrm{~m} / \mathrm{s}$ & $39^{\circ} \mathrm{C}$ & 1,2 \\
\hline & COR 2B & $25^{\circ} \mathrm{C}$ & $58 \%$ & $0,41 \mathrm{~m} / \mathrm{s}$ & $30^{\circ} \mathrm{C}$ & 0,8 \\
\hline \multirow{2}{*}{ COR3 } & COR 3A & $24^{\circ} \mathrm{C}$ & $59 \%$ & $0,58 \mathrm{~m} / \mathrm{s}$ & $44^{\circ} \mathrm{C}$ & 1,4 \\
\hline & COR 3B & $24^{\circ} \mathrm{C}$ & $59 \%$ & $0,73 \mathrm{~m} / \mathrm{s}$ & $41^{\circ} \mathrm{C}$ & 1,2 \\
\hline \multirow{2}{*}{ CAN } & CAN A & $25^{\circ} \mathrm{C}$ & $56 \%$ & $1 \mathrm{~m} / \mathrm{s}$ & $35^{\circ} \mathrm{C}$ & 1 \\
\hline & CAN B & $25^{\circ} \mathrm{C}$ & $57 \%$ & $0,1 \mathrm{~m} / \mathrm{s}$ & $33^{\circ} \mathrm{C}$ & 1 \\
\hline \multirow{2}{*}{$\mathrm{COU}$} & COUA & $25^{\circ} \mathrm{C}$ & $57 \%$ & $0,7 \mathrm{~m} / \mathrm{s}$ & $42^{\circ} \mathrm{C}$ & 1,4 \\
\hline & COUB & $25^{\circ} \mathrm{C}$ & $56 \%$ & $0 \mathrm{~m} / \mathrm{s}$ & $38^{\circ} \mathrm{C}$ & 1,3 \\
\hline \multirow{2}{*}{ PAR } & PARA & $26^{\circ} \mathrm{C}$ & $54 \%$ & $1 \mathrm{~m} / \mathrm{s}$ & $48^{\circ} \mathrm{C}$ & 2 \\
\hline & PARB & $24^{\circ} \mathrm{C}$ & $58 \%$ & $1 \mathrm{~m} / \mathrm{s}$ & $31^{\circ} \mathrm{C}$ & 0,7 \\
\hline
\end{tabular}


and PMV were at $24-26^{\circ} \mathrm{C} \& 31-48^{\circ} \mathrm{C}, 54-60 \%, 0-1.1$ $\mathrm{m} / \mathrm{s}$, and 0.7-2 (neutral-warm), respectively. This data derivative were also to be discussed in more depth, within this study.

\section{Results and Discussion}

This chapter discussed the results of the research, which were related to the data interpretation, obtained from the simulation outcomes. This data was analyzed using ANOVA and regression approaches, in order to see the significance of the problem. PMV maps from the case studies were also presented, in order to help interpret the results of the data.

The ANOVA and line diagram (Figure 5 and Figure 6) showed the linear change in thermal comfort at 08:00 am - 04:00 pm. Therefore, the discussion of PMV maps focused on the phenomena that occurred per two hour unit time.

The average PMV value at the Universitas Kebangsaan building complex was on the thermal sensation index, from slightly cool until hot. Changes in the average PMV value were linear with changes in air temperature and humidity, with wind speeds having quite different data trends. When the wind speed increases, the PMV value and the temperature also increased, during the day. Also, the average wind speed at the research area was $0.68 \mathrm{~m} / \mathrm{s}$. This value was in the slightly calm and low category, for the outdoor space scale (Stewart, 2004). Moreover, the wind speed does not have a significant effect on PMV in the area (Figure 6). The PMV value in the study area was also more influenced by air temperature and relative humidity (Figure 6). These results further indicated that, in order to establish outdoor thermal comfort in the Universitas Kebangsaan area, the various aspects that controls the air temperature and

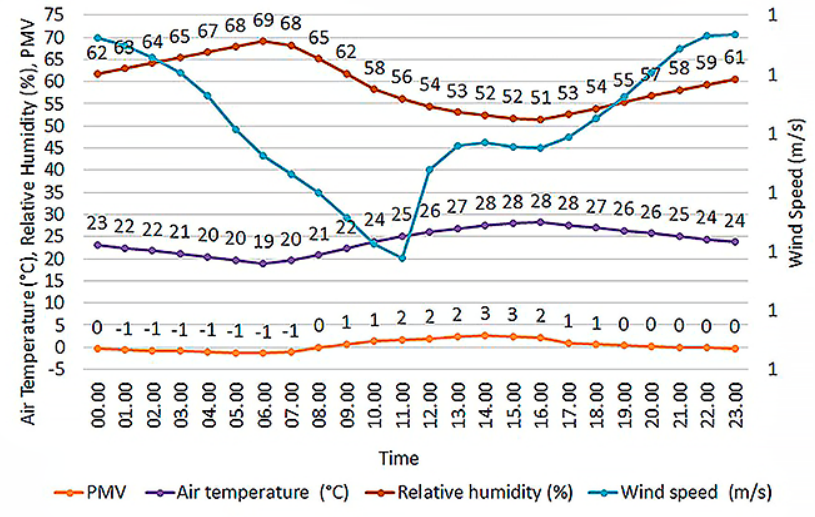

(a)

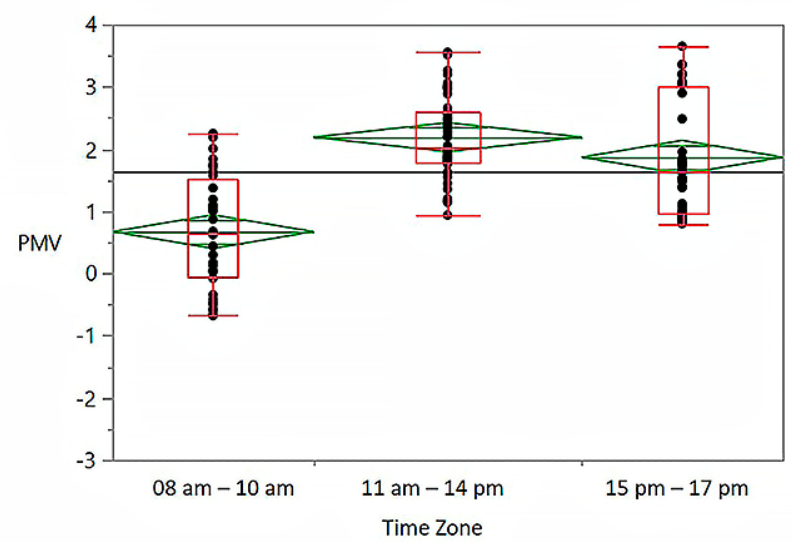

(b)

Figure 5. (a) average thermal condition data in 24 hours; (b) average thermal conditions in 3 time zones
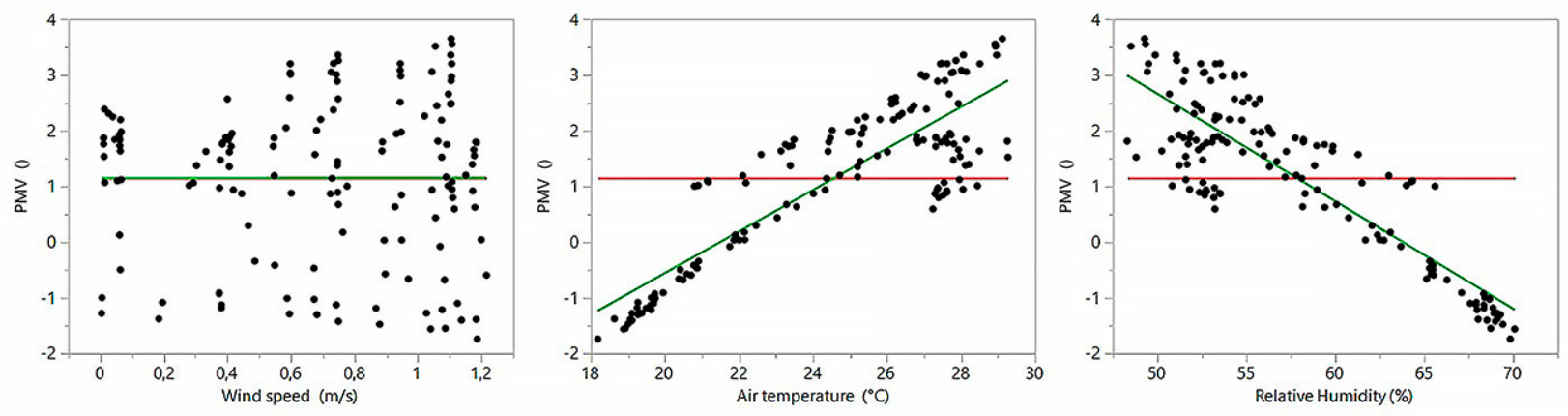

\begin{tabular}{ccccc}
\hline Term & Estimate & Std Error & t Ratio & Prob $>|\mathbf{t}|$ \\
\hline Intercept & 1,1460349 & 0,245926 & 4,66 & $<, 0001^{*}$ \\
Wind speed $(\mathbf{m} / \mathbf{s})$ & 0,0072677 & 0,312428 & 0,02 & 0,9815 \\
Air Temperature $\left({ }^{\circ} \mathbf{C}\right)$ & 0,3725089 & 0,018676 & 19,95 & $<, 0001^{*}$ \\
Relative Humidity (\%) & $-0,192881$ & 0,008935 & $-21,59$ & $<, 0001^{*}$ \\
\hline
\end{tabular}

Figure 6. Regression value between PMV and other thermal factors 

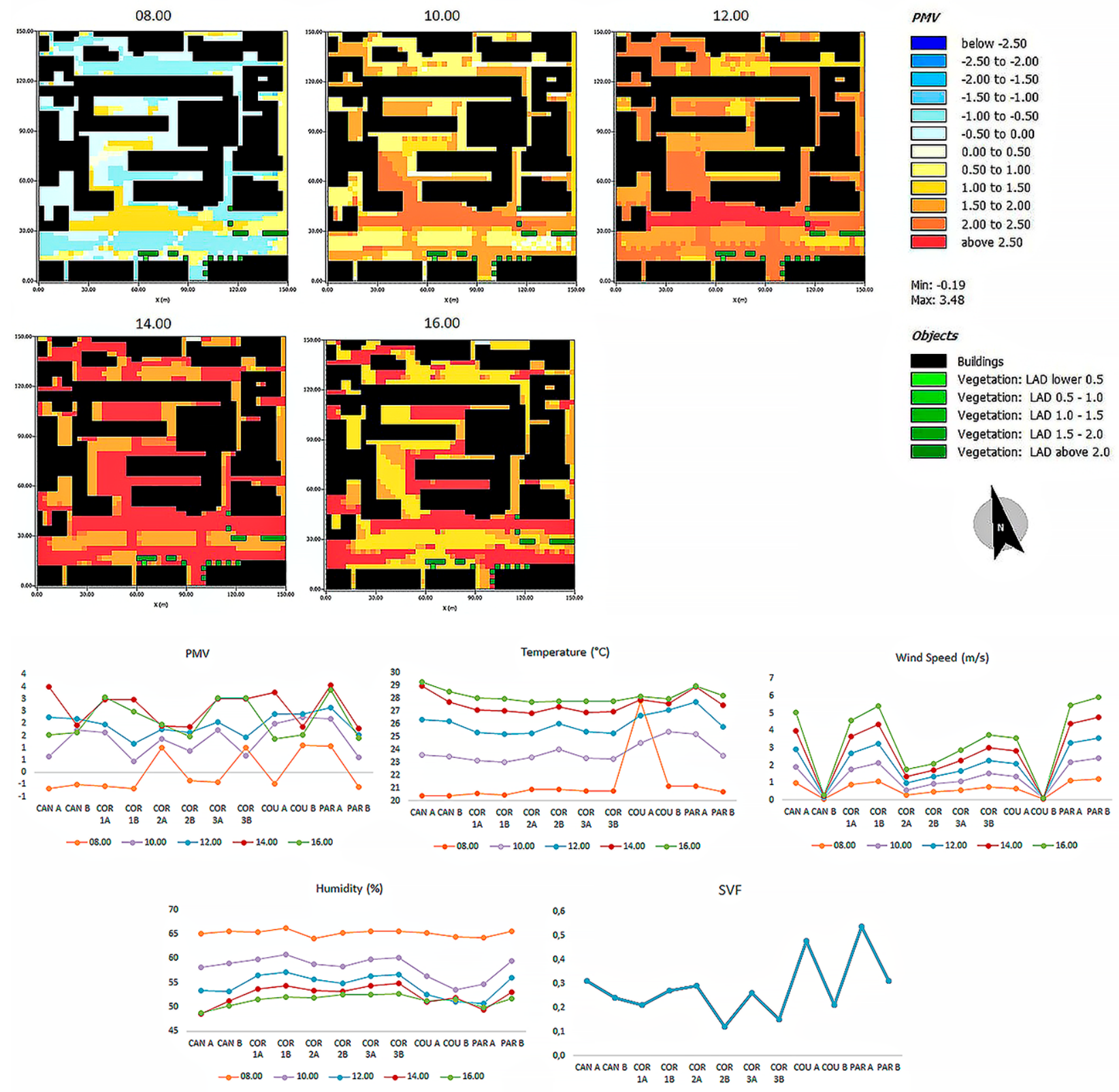

Figure 7 . Simulation result for 5 different time $(08.00,10.00,12.00,14.00,16.00)$

relative humidity of the campus environment, were considered.

The PMV maps in the morning showed almost the entire area in a comfortable condition, which was indicated by a light blue colouration (Figure 7). The Anova analysis (Figure 5) also showed the range of PMV values in the morning at $-0.68-2.24$, with a slightly cool-warm thermal sensation. This condition was due to the position of the sun irradiation in the morning, which was not right above the building. These conditions made a lot of outdoor space shaded, by the surrounding buildings. However, areas with less shadow exposed to direct sunlight, had a higher PMV value. The higher PMV value was further shown with yellow colour, or at PAR A, COU B, and COR 2A areas. Generally, areas with less of shadow had large open space.
Towards the time of day at 10:00 am, the outdoor conditions were getting more uncomfortable, which was indicated by light-dark yellow, with a value of $0.5-$ 2.5 (Figure 7). This condition reduced the activities in the outdoor space. The Anova analysis also showed a thermal sensation that was slightly cool-hot during the day, with the PMV value ranging from 0.93-3.55 (Figure 5). This condition was due to the changing position of the sun, as it also reduced the shadow area. In the middle of the day, when the sun's position was at $90^{\circ}$ or right on the top of the building, the shadow of the outdoor area became less. These conditions allowed the outdoor area become more uncomfortable, as the higher PMV value ranged from 1.50-2.50, with a slightly warm-hot thermal sensation. The most uncomfortable conditions were at 02:00 pm-03:00 pm, 
with a PMV index value of 3 , which was also linear with the increasing air temperature, at $28^{\circ} \mathrm{C}$.

The thermal maps in the afternoon further showed a lower PMV value, than during the day (Figure 7). The outdoor area having lower PMV was close to buildings and trees. These conditions made the outdoor area become more shading, although there was still a PMV value above 2.5 in some areas. The thermal sensation felt in the afternoon was slightly coolhot, with the PMV value ranging from 0.79-3.64. The cause of this condition was due to the fact that the average temperature in the afternoon was still high, similarly as during the day. The higher air temperature was also caused by the building density and the type of pavement material in the campus area. Those conditions made solar radiation to be absorbed more by the material, as much rays were distributed in the area. The use of surface materials should also consider its sustainability in terms of circulation, water infiltration, maintenance, and also thermal comfort (Ramadhan et al., 2018). The use of surface materials that do not respond to heat was very important to the achievement of outdoor thermal comfort. This also had an impact on the active social interactions at the area, which was the case of students' relationships.

In addition to surface materials, the low wind distribution in the area also made radiation to be released slowly. According to Syafrina, building density blocked the wind flow, and caused heat to be trapped longer in an area (Syafrina et al., 2020). Therefore, it was necessary to consider building density and preparation of open space planning, in order to make a better wind distribution in the campus area.

The most comfortable sub zone was at PAR B, with the average PMV value of 0.65 . This sub zone had a higher shadow intensity throughout the day, which resulted in the lower radiation received in this area.

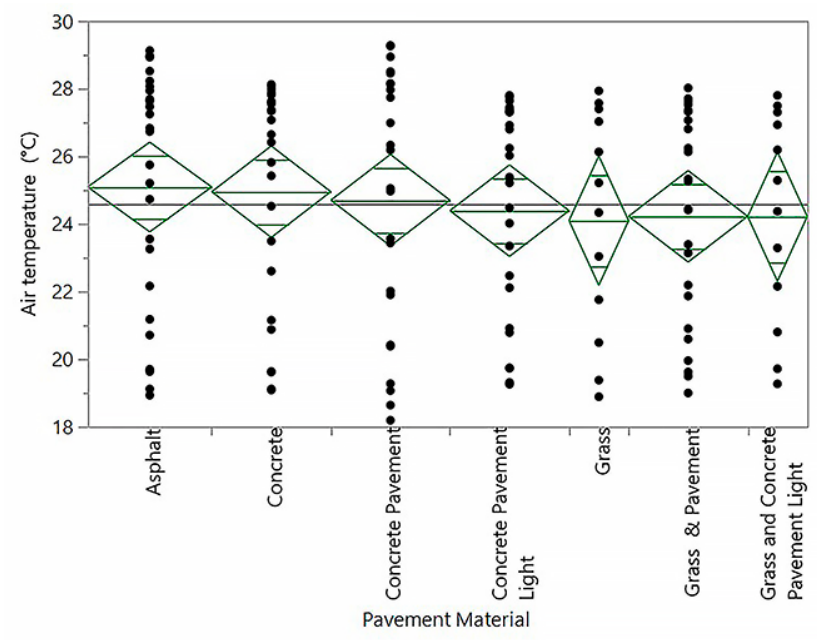

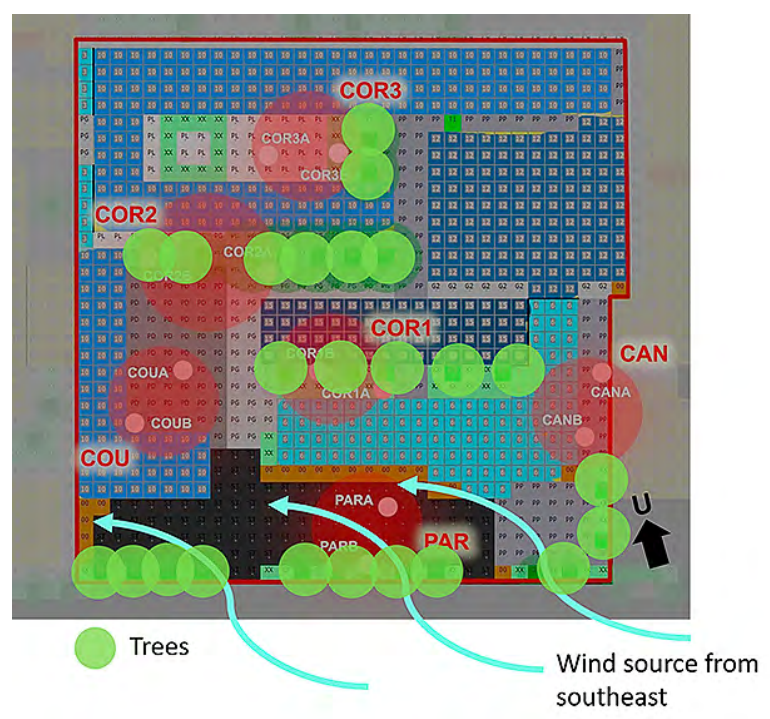

Figure 8. wind direction illustration

The shadow in this sub zone resulted from wide canopy plantations, as the previous research stated that trees and vegetation cooled the air by shade, and reduced the amount of sunlight hitting the ground (EPA, 2020). The area having large open space at the front of the campus, made this zone connected directly to the wind, which occurred from the Southeast. Those conditions were observed to have affected the decreased air temperature (Figure 8). According to a study conducted by Bajsanski et al. (2019), the mitigation overheatingof horizontal and vertical surfaces reduced up to $7 \%$, through the disposition of different trees.

The most uncomfortable sub zone was at PAR A, with the average PMV value at 1.74 . This area became the least of shadowing, throughout the day. The asphalt pavement characteristics in this area had relatively high heat capacity, automatically affecting the thermal environment, as an effective heat absorbent and producer (Halliday et al., 2007). Also, Figure 9

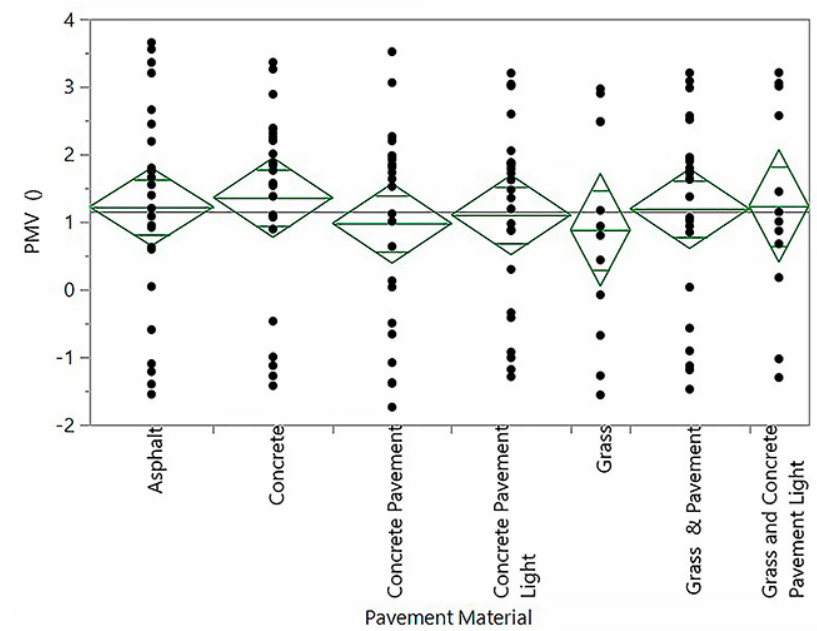

Figure 9. (a) Anova diagram of pavement material due to air temperature and (b)PMV 

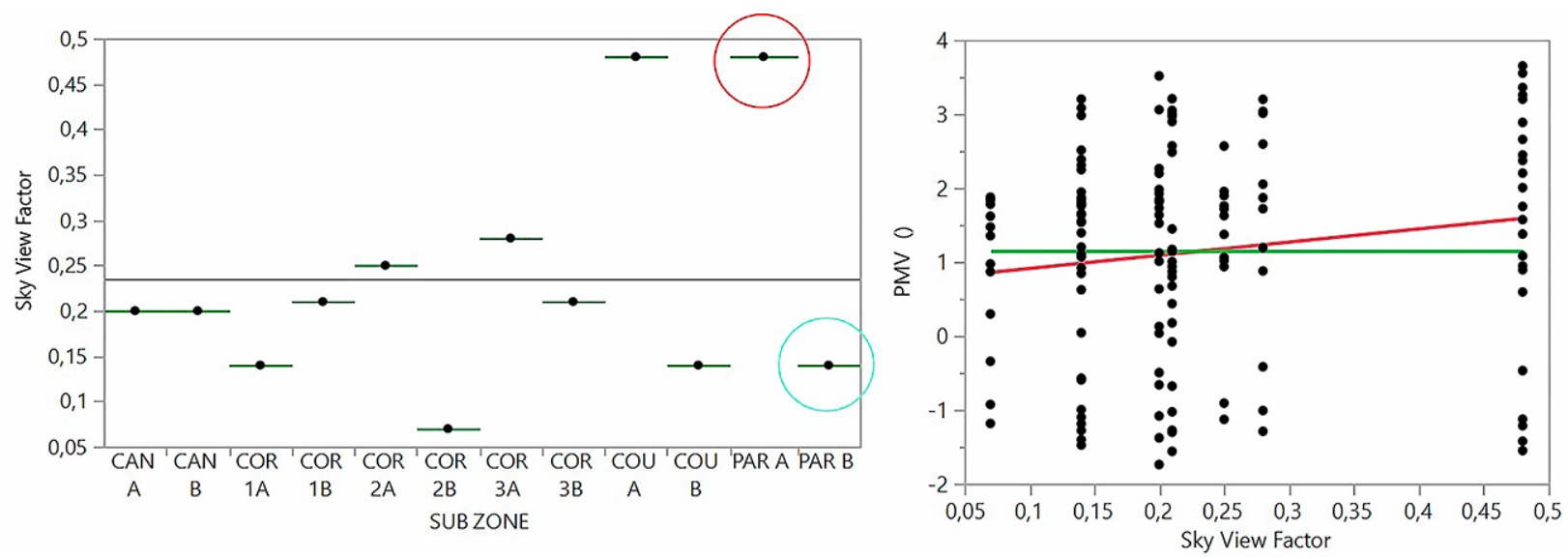

Figure 10. (a) Average of Sky View Factor in Sub Zone; (b) regression value between Sky View Factor and PMV

showed that the differences in character of the land cover material, had different effects on thermal condition.

The Anova diagram in Figure 9 showed that the areas using asphalt and concrete as land cover, had higher temperature than others. However, the lower temperature area used grass material as land cover. The temperature difference also affected PMV, the higher conditions caused greater Predicted Mean Vote.

The two sub zones located in the same area showed that differences in physical characteristics affected thermal conditions, in that zone. The shading factor in the outdoor space further showed that higher SVF value resulted in greater PMV parameter, while also allowing the area become more uncomfortable, due to the fact that it received large solar radiation. Also, the higher SVF value closer to 1 indicated the wider open space, which enabled the greater solar radiation received in the area (Figure 10).

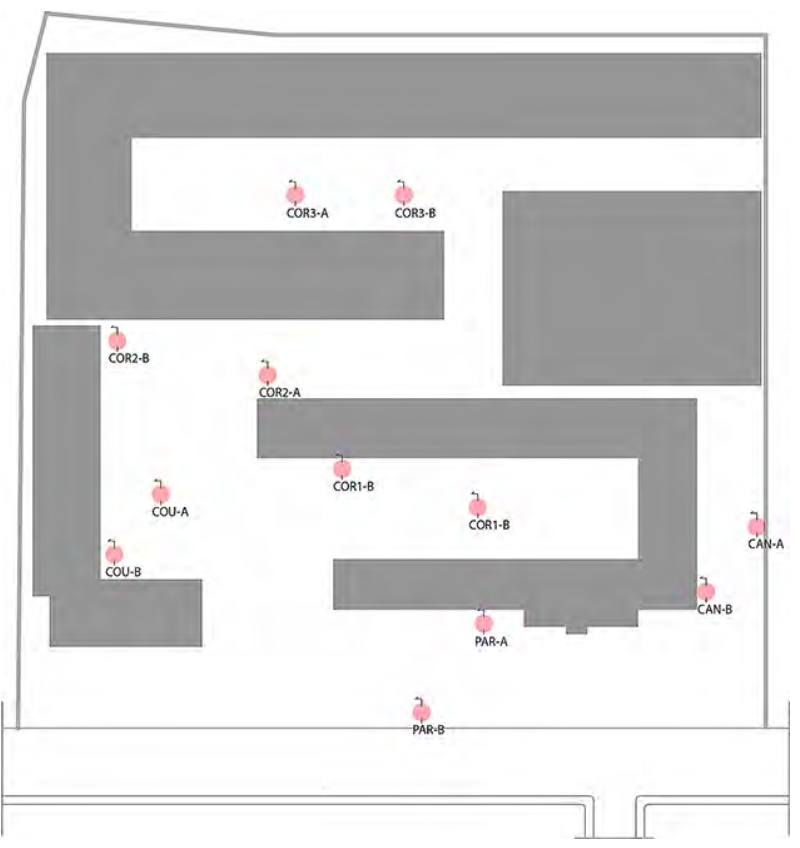

Figure 11. Twelve points location in case study (six zones)
Further discussion was developed in more depth, in order to observe the characteristics and differences that affected thermal comfort. The following was a discussion of the 6 zones (12 points), based on Figure 11. Based on the range of PMV conditions from 6 zones (12 points), results were observed to vary between 08.00-16.00. This difference further showed that each zone had a different thermal response.

\section{Corridor 1 Zone (COR1)}

Zone 1 was divided into two corridors (COR1-A and COR1-B), with a park between the two buildings. Each of these corridors was bounded by buildings and parks, with different orientations. COR1-A had the north and south bordering the garden and class buildings, respectively. However, the COR1-B borders the park and buildings to the south and north (Figure 11 and 12), respectively. This zone further extended from the East-West direction, with the east and west being bordered by a closed corridor and open space, respectively.

The corridors in this zone had a high occupancy rate, with classrooms and libraries around them. Also, along this corridor, some seats caused students to gather, discuss, or carry out assignments. This corridor had an area smaller than the width of the others, and was the greenest, due to havingquite a lot of vegetation and grass.

In the simulation, COR1-B and COR1-A received direct radiation from sunlight for 6 and $3 \mathrm{hrs}$, from 10:00-16:00 \& 13.00-16.00 durations, respectively. Also, the highest heat events at COR1-A \& COR1-B occurred at $15.00 \& 14.00$, with PMV values of +3 and, +2.5 , respectively. Judging from the characteristics of these two corridors, COR1-B had a longer duration of sun exposure than COR1-A.

The difference in radiation reception was because COR1-A had a smaller SVF than COR1-B, with a value of 0.2. Previous research further stated that a higher SVF value indicated the reduced shade density of 

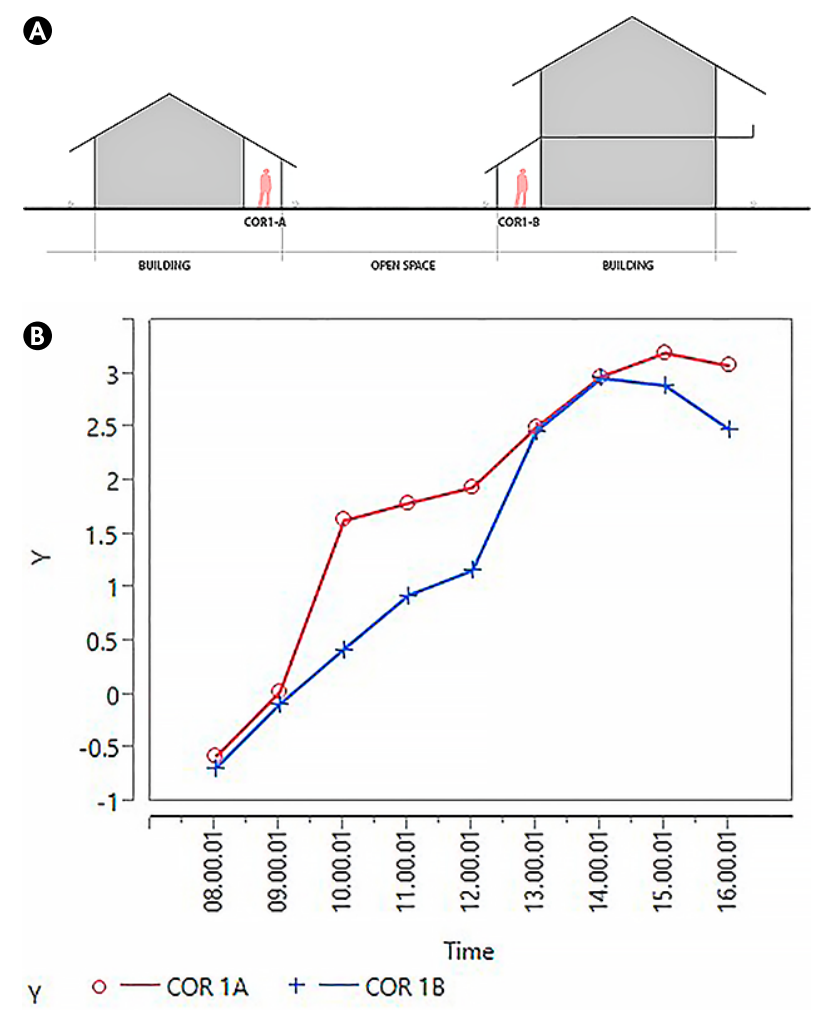

Figure 12. (a) Section of COR1A and COR1B (b) Comparison of PMV at 2 points location in the COR1 zone

an area, as radiation reception was high, therefore providing a higher heat effect (Dirksen et al., 2019). However, the Predicted Mean Vote difference graph showed that COR1-A had a higher PMV value than COR1-B.

These results indicated that the shading character shown by the SVF was also influenced by other physical character factors, such as the height of the surrounding buildings, presence of vegetation, and the type of land cover used. COR1-A had grass and paved surfaces, with the height of the surrounding buildings consisting of 1 floor $( \pm 3 \mathrm{~m})$. However, the land cover type of COR1-B consisted of grass, with the height of the surrounding buildings having 2 floors $( \pm 6 \mathrm{~m})$.

The taller the building with sufficient vegetation, the lower the temperature around the area (Paramita \& Fukuda, 2013). Lower temperatures also increasingly affected the thermal comfort of an area, with the type of land cover similarly influencing radiation absorption. Pavement cover also absorbed more radiation than those of the non-pavement. The radiation that was absorbed more on a surface, emitted a higher temperature (Olgyay et al., 2015).

The higher radiation absorption was observed from the Mean Radiant Temperature (MRT) value. The MRT is the radiation from the surface of a place or the human body, as it is also an essential factor in thermal comfort (Olgyay et al., 2015). COR1-A \& COR1$\mathrm{B}$ had a higher MRT value of $41 \& 36^{\circ} \mathrm{C}$, respectively.
The difference in the MRT value from the simulation results also reinforced that differences in physical characteristics, such as building height and land cover caused distinguished thermal comfort in an area.

\section{Corridor 2 zone (COR2)}

COR2 was double corridors (COR2-A and COR2-B) between two buildings and the field. This corridor extended in an East-West direction, where the areas to the east and west were bordered by opened and closed corridors with buildings, respectively. COR2-A was located in a circulation path with concrete pavement, between two buildings. However, COR2-B was located close to trees, between buildings, and open fields, which had large pavement covers (Figure 11 and 13). The corridors in this zone were circulation areas and campus sports fields, which were often used for student activities.

In the simulation, these two corridors received direct radiation from the sun for $4 \mathrm{hrs}$, from 10:0014:00. The highest heat events at COR2-A \& COR2-B further occurred at 15.00 and 13.00 , with a PMV value of approximately $+1.5 \&+2.5$, respectively.

The difference in PMV also showed that COR2-A had a higher PMV value than COR2-B (Figure 12). The difference in PMV was due to the fact that COR2$A$ had a higher SVF value than COR2-B, at 0.3. The characteristics of COR2-B, which were the closeness and highness in the percentage of vegetation and trees,
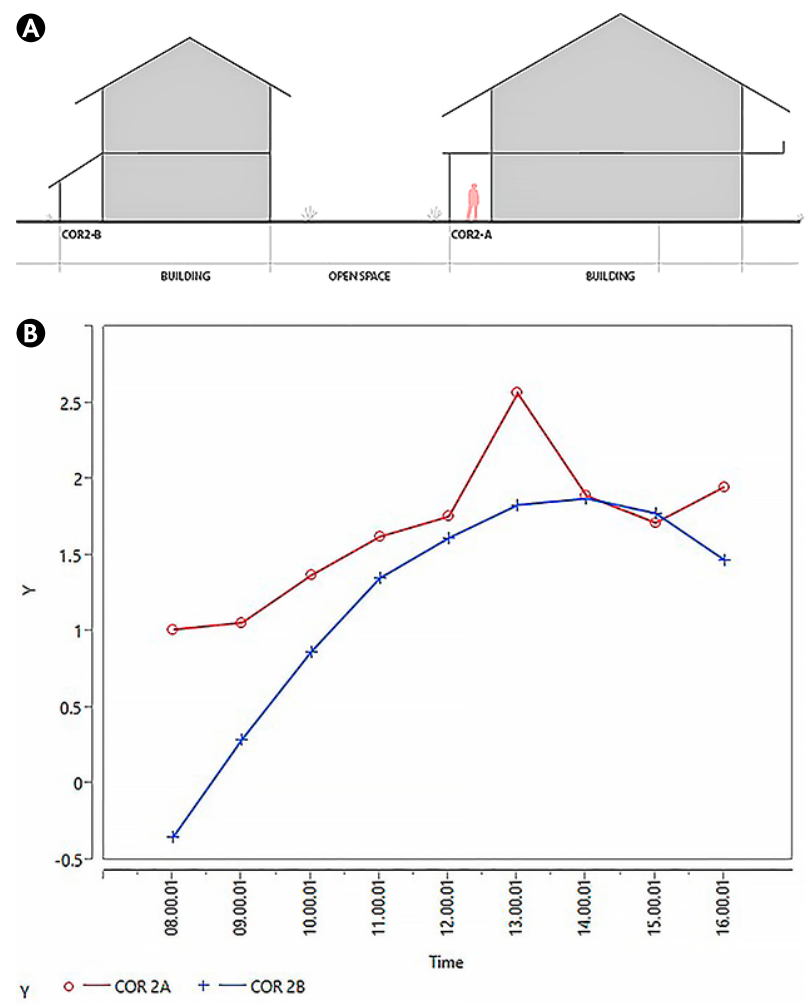

Figure 13. (a) Section of COR2A and COR2B (b) Comparison of PMV at 2 points location in the COR2 zone 
made this area possess a lower PMV than COR2-A. As explained in previous research, the character of land cover and vegetation influenced the radiation received in an area (Olgyay et al., 2015). Besides that, the area of COR2-B bordering the open field, made the wind received higher by $0.41 \mathrm{~m} / \mathrm{s}$. The movement of the wind functioned in the transfer of heat from an area or material to another (Gunawardena et al., 2017; Wonorahardjo, 2012). For this reason, the openness of an area was observed to flow smoothly (Syafrina, 2020).

\section{Corridor 3 zone (COR3)}

Zone 3 was two corridors (COR3-A and COR3-B) located in the northern area of the campus site. COR3-A was observed to border open spaces to the north, and buildings to the south. However, COR3-B bordered buildings to the north, and parks to the south. The east and west sides of these two corridors were bordered by open spaces (Figure 11 and 14). Also, COR3A was surrounded by a 2-story building, while COR3$\mathrm{B}$ was located under a tree.

COR3-A and COR3-B received sunlight radiation for 7 and $3 \mathrm{hrs}$, from $9.00-16.00 \& 13.00-16.00$, respectively. The duration of this exposure was almost the same as zone 1, where the corridor bordering the garden in the south obtained less exposure time. For SVF, COR3-A \& COR3-B had values of 0.3 and 0.2 , respectively.
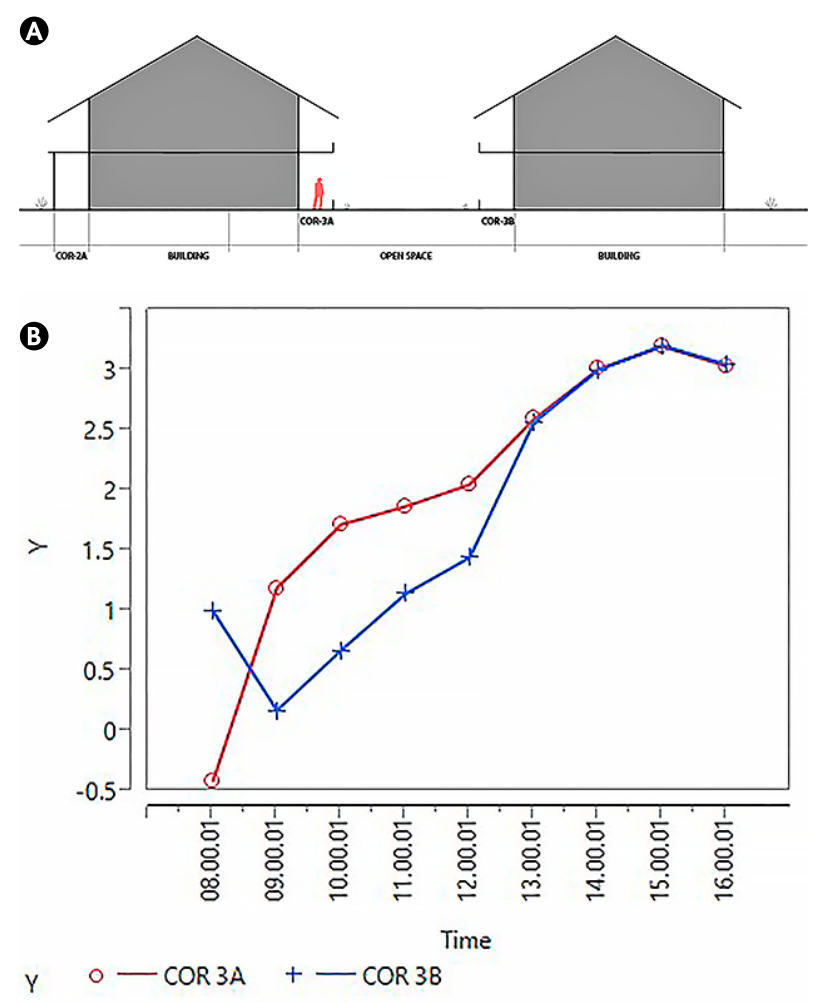

Figure 14. (a) Section of COR3A and COR3B (b)

Comparison of PMV at 2 points location in the COR3 zone
The simulation results further showed that when the simulating process started at 8:00 AM, COR3-A and COR3-B had PMV values of +0.5 and +1 , respectively. Afterwards, COR3-B experienced a decrease in PMV at 9.00, which then increased simultaneously with the value of COR3-A till 13.00, with the second Predicting Mean Vote parameter reaching +2.5 . After 11.00 PM, the PMV value then started increasing for both corridors, until it reached the hot peak $(\mathrm{PMV}+3)$ at 15.00. The simulation results showed that COR3-B had the same PMV value as COR3-A, when both received sunlight at 13.00 to 16.00 . Also, SVF had a significant role in the PMV value, as this condition was the opposite of the simulation results in zone 1. However, it also had similarities in terms of other physical characteristics, such as land cover. More extensive pavement cover and less vegetation resulted in the lower thermal comfort of an area.

\section{Canteen zone (CAN)}

The canteen zone was located to the east of the site. Within this zone, two points were simulated (CAN-A and $\mathrm{CAN}-\mathrm{B}$ ), as shown in Figure 15.

The simulation point for CAN-A was in the middle area of the canteen zone, while CAN-B was located in the circulation between the buildings. The length of irradiations that occurred on CAN-A and CAN-B

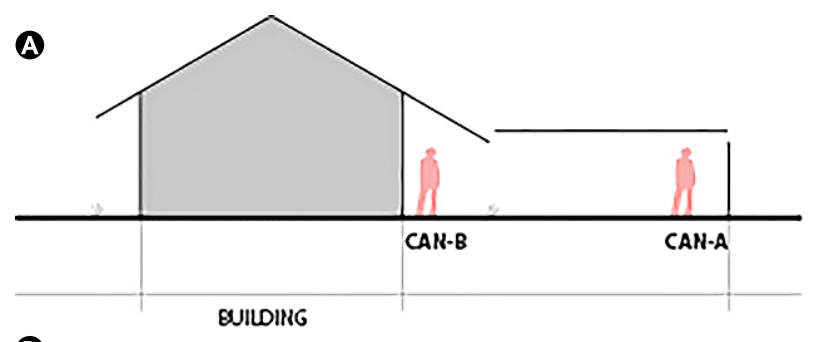

B

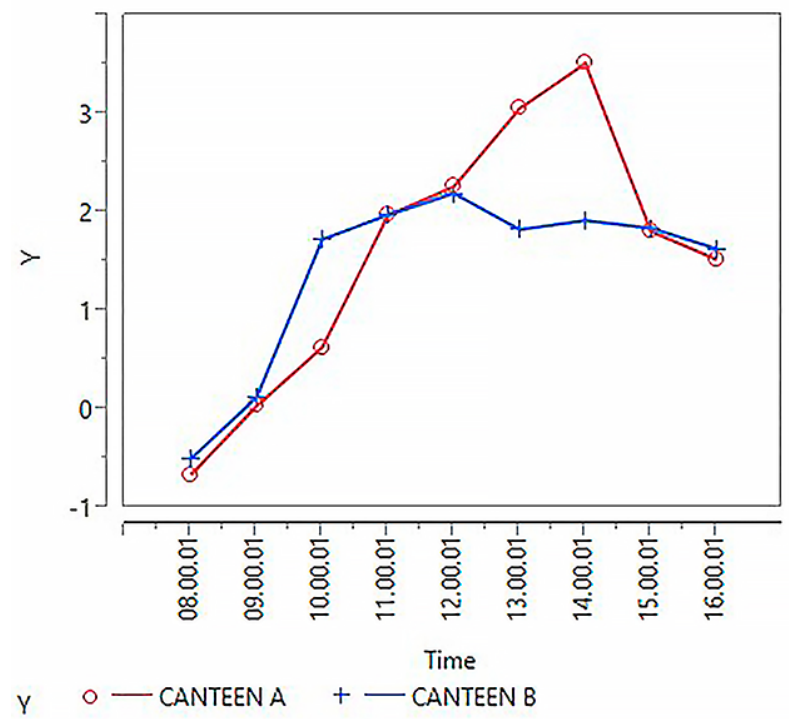

Figure 15. Section of CAN-A and CAN-B (b) Comparison of $\mathrm{PMV}$ at 2 points location in the CAN zone 
was 3 and 2 hrs, starting from 11.00-14.00 \& 10.0012.00 , respectively. Also, the surfaces of the two corridors were concrete pavement, as both further had SVF values of $20 \%$.

The simulation results then showed that CANA had a very high PMV value during the day, than CAN-B. This condition occurred at 14.00 , where CAN-A received solar radiation for $3 \mathrm{hrs}$. When compared with CAN-B, the PMV value at 14.00 was approximately +1.7 . The highest PMV value for CAN-B further occurred at 12.30 , with a value of +2 . The graph of the difference in PMV values also showed that CAN B had a higher PMV in the morning than CAN A, which was around 08.00-10.00 hrs. This condition was due to the duration of exposure experienced by an area. The position of CAN-B was directly exposed to solar radiation, while CAN$A$ received a shadow from the building, to the east. During the day to evening, the CAN-B area became lower than CAN-A, due to the fact that the sun's position had changed. This resulted in the CAN-B area obtaining more shadow from the building next to it (Figure 15). CAN-A was located at the intersection of 2 corridors, and was quite far from the building, with the area having a higher wind speed. However, wind speed had no significant effect in this area, as the same average PMV value on both corridors at 1 , was observed.

\section{Court zone (COU)}

The field zone was an open area used for sports fields, as there were two points of simulation carried out in this zone, namely COU-A and COU-B. COU-A and COU-B were located in the middle area of the field, and between the building with the open space, respectively (Figure 11 and 16).

Both simulation points had a concrete base surface, and do not have vegetation. This surface influenced the temperature conditions in the surrounding environment, as it increased the PMV value. The durations of radiation that occurred in COU-A and COUB were $6 \& 4$ hrs, starting at 9.00-15.00 \& 08.00-12.00, respectively. Also, the SVF values for both COU-A and COU-B were $0.5 \& 0.2$, respectively.

From the simulation results, COU-A and COU-B had the highest PMV values at $15.00 \& 12.00$, with more than +3 and +2.5 , respectively. When viewed from the irradiation time, each simulation point reached the highest peak of PMV at the end of the simulating process. The SVF also had a significant effect on the PMV value, with COU-A at 0.5, making it a hot simulation point. Also, a considerable SVF made the Mean Radiant Temperature (MRT) value higher. A higher MRT also caused the PMV value to be greater, especially during the day at COU-A point. In the
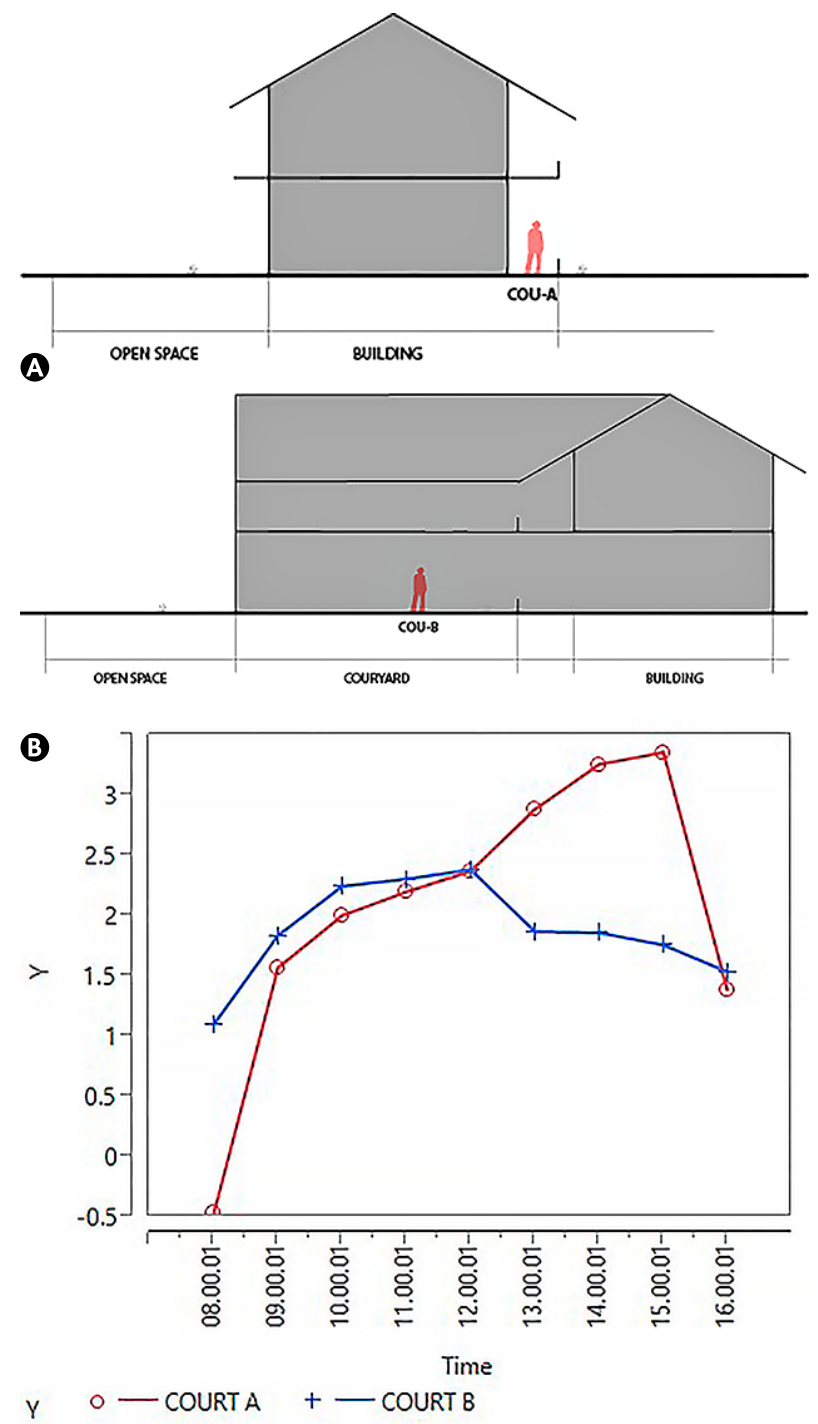

Figure 16. (a) Section of COU-A and COU-B (b) Comparison of $\mathrm{PMV}$ at 2 points location in the COU zone

morning, COU-A was still lower than COU B, due to the fact that the area (COU-A) received shadows on a 3-storey building. This was also due to the fact that solar radiation had not been received much (Figure 8). Besides that, the COU-A was located in the opened field, making this area receive higher winds than COU-B, which was located very close to the building, and obstructed from the direction of the wind movement, flowing from the Southeast. This condition was the same as the previous five zones, which showed that the density of an area influenced wind movement. Although in some zones, the wind speed has no significant effect. This condition also indicated that wind was not very effective in increasing thermal comfort, due to its small velocity value. Therefore, even though improvements need to be made to build a better wind environment as mentioned by Liu et al. (2019), it was useless when the initial velocity occurred to be too small. 


\section{Parking zone (PAR)}

The parking zone was located at the south of the site, which was the entrance area used for assembling vehicles. This zone consisted of two simulation points, namely PAR-A and PAR-B. The PAR-A zone was located in the middle of the parking area. However, PAR-B was located in the parking area and under a tree.

PAR-A was located in the middle of the parking area without any roof covering it, as the SVF value obtained was 0.5 , while PAR-B was at 0.3. PAR-A also has extended irradiation of $8 \mathrm{hrs}$ from $8.00-16.00$, while PAR-B does not get sunlight in one day. Also, PAR-A and PAR-B consisted of asphalt, for surface materials.

The simulation parameters differed quite a lot between PAR-A and PAR-B, resulting in the PMV values being different between the two. PAR-A was also observed to have a higher PMV value than PAR-B. The highest PMV values that occurred at PAR-A and PAR-B wete more than +3 and +1.5 , at 15.00 and 13.00 , respectively. Judging from the existing parameters, the size of the SVF and the length of exposure, had a significant influence on the value of PMV in PAR-A. Also, it was the same with some of the zones previously discussed, which stated that the presence of vegetation had a significant effect on differences, in thermal comfort. Trees produced a significant increase in human thermal comfort, due to the fact that they reduced and absorbed solar radiations, which were used to reap water on the leaves (Oke,
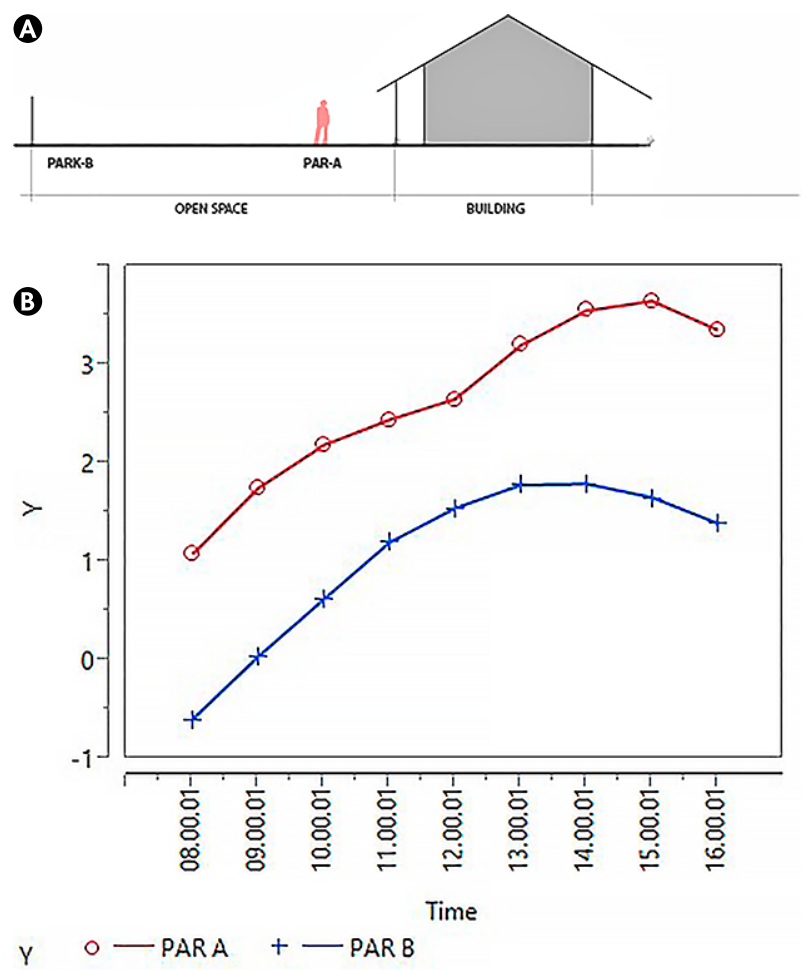

Figure 17. Section of PAR-A and PAR-B (b) Comparison of PMV at 2 points location in the PAR zone

1987; Zheng et al., 2018). As observed in Table 4, PMV at the two points had a very significant difference, due to the radiation received also being different.

\section{Conclusion}

Due to the thermal comfort analysis in this study, future current conditions and design potentials were identified. This evaluation study showed that the outdoor zone in the Universitas Kebangsaan, which was located in Bandung urban area, had low thermal comfort value, due to several factors. It also had different thermal comfort conditions, due to differences in physical characteristics in each zone. Some of these factors were:

1. The SVF as indicators of the shading factor should be supported by the presence of vegetation, and the use of pavement material.

2. Although the wind speed factor does not really affect the thermal comfort in the outdoor space, the interconnection between open spaces should make breeze distribution in the area better.
This study also offered direction for campus planning, in order to maintain the optimal capacity of the natural environment, such as:

1. Strategizing to create a better shadowing factor in the outer space, supported by controlling the use of pavement materials.

2. Controlling the density of campus buildings, by making open spaces more permeable for better wind distribution in the area.

The outdoor thermal considerations in this study were also expected to create a more comfortable environment, especially for educational buildings in urban areas, as it is supposed to be fully utilized, while reducing the influence of heat into the building.

\section{Acknowledgments}

The authors are grateful to the Ministry of Research and Technology/National Research and Innovation Agency of Republic Indonesia, for supporting the progress of this study. Grant number 458/UN40.D/PT/2020 under the LPPM University education in Indonesia, was also obtained for the simulation of the building performance process in the design studio . 


\section{References}

Abdallah, A. S. H., Hussein, S. W., \& Nayel, M. (2020). The impact of outdoor shading strategies on student thermal comfort in open spaces between education building. Sustainable Cities and Society, 58, 102124. https://doi.org/10.1016/j.scs.2020.102124

Badan Meteorologi Klimatologi Geologi. (2020). Akses Data. Retrieved from http://dataonline.bmkg. go.id/akses data

Bajsanski, I., Stojakovic, V., \& Milosevic, D. (2019). Optimizing Trees Distances in Urban Streets for Insolation Mitigation. Geographica Pannonica, 23(4), 329-336. https://doi.org/10.5937/gp23-24242

Dirksen, M., Ronda, R. J., Theeuwes, N. E., \& Pagani, G. A. (2019). Sky view factor calculations and its application in urban heat island studies. $U r$ ban Climate, 30, 100498. https://doi.org/https://doi. org/10.1016/j.uclim.2019.100498

EPA. (2020). Trees and Vegetation: Using Trees and Vegetation to Reduce Urban Heat Islands. Retrieved from https://www.epa.gov/heatislands/using-trees-and-vegetation-reduce-heat-islands

Fanger, P. O. (1970). Thermal comfort. Analysis and applications in environmental engineering. Copenhagen: Danish Technical Press.

Ghaffarianhoseini, A., Berardi, U., Ghaffarianhoseini, A., \& Al-Obaidi, K. (2019). Analyzing the thermal comfort conditions of outdoor spaces in a university campus in Kuala Lumpur, Malaysia. Science of the Total Environment, 666, 1327-1345. https://doi. org/10.1016/j.scitotenv.2019.01.284

Gonzalez, R. R. (1995). Biophysics of Heat Exchange and Clothing: Applications to Sports Physiology. Medicine, Exercise, Nutrition \& Health, 4(5), 290305. Retrieved from http://articles.sirc.ca/search. cfm?id=382807\%0Ahttp://search.ebscohost.com/ login.aspx?direct=true $\& \mathrm{db}=\mathrm{sph} \& \mathrm{AN}=\mathrm{SPH} 382807$ \&lang $=e s \&$ site $=$ ehost-live\&scope $=$ site

Gunawardena, K. R., Wells, M. J., \& Kershaw, T. (2017). Utilising green and bluespace to mitigate urban heat island intensity. Science of The Total Environment, 584-585, 1040-1055. https://doi.org/10.1016/j. scitotenv.2017.01.158

Halliday, D., Resnick, R., \& Walker, J. (2007). Fundamentals of Physics Extended. Wiley. Retrieved from https://books.google.co.id/ books?id=xAVuxgEACAAI

Huang, Z., Cheng, B., Gou, Z., \& Zhang, F. (2019). Outdoor thermal comfort and adaptive behaviors in a university campus in China's hot summercold winter climate region. Building and Environment, 165, 106414. https://doi.org/10.1016/j.buildenv.2019.106414
Hulukati, W., \& Djibran, M. R. (2018). Analisis Tugas Perkembangan Mahasiswa Fakultas Ilmu Pendidikan Universitas Negeri Gorontalo. Jurnal Bikotek, 02(01), 73-80.

International Organization for Standardization. (2005). ISO 7730 2005-11-15 Ergonomics of the Thermal Environment: Analytical Determination and Interpretation of Thermal Comfort Using Calculation of the PMV and PPD Indices and Local Thermal Comfort Criteria. ISO. Retrieved from https:// books.google.co.id/books?id=p3YcoAEACAAI

Jeong, D., Park, K., Song, B., \& Kim, G. (2015). Validation of ENVI-met PMV values by in-situ measurements. ICUC9 - 9th International Conference on Urban Climate Jointly with 12th Symposium on the Urban Environment.

Kusyanto, M., Sinaga, I. A., Triyadi, S., Faisal, B., Wonorahardjo, S., \& Jurizat, A. (2019). Space Quality of Two Indonesian Mosques: Architectural Style, Development Process and Environmental Condition. American Journal of Environmental Sciences, 15(1SE). https://doi.org/10.3844/ajessp.2019.23.41

Liu, A., Xu, Q., Gao, J., Xu, Z., \& Han, L. (2019). Improving Schoolyard Wind Environments: Case Studies in Two Schools in Nanjing. Geographica Pannonica, 23(4), 256-268. https://doi.org/10.5937/ gp23-24183

Meteoblue. (2020). Climate $6.93^{\circ} \mathrm{S} 107.63^{\circ} \mathrm{E}$. Retrieved from https://www.meteoblue.com/en/weather/historyclimate/climatemodelled/-6.927N107.626E

Muljati, S., Triwinarto, A., Utami, N., \& Hermina. (2016). Gambaran Median Tinggi Badan dan Berat Badan Menurut Kelompok Umur pada Penduduk Indonesia yang Sehat Berdasarkan Hasil Riskesdas 2013 (Description of Median Number of Weight and Height Classified by Age Group on Healthy Indonesian Citizens Based on Riske. Penelitian Gizi Dan Makanan, 39(2), 137-144.

Oke, T. R. (1987). Boundary Layer Climates. Abingdon: Routledege \& CRC Press.

Olesen, B. W., \& Parsons, K. C. (2002). Introduction to thermal comfort standards and to the proposed new version of EN ISO 7730. Energy and Buildings, 34(6), 537-548. https://doi.org/10.1016/S03787788(02)00004-X

Olgyay, V., Olgyay, A., Lyndon, D., Olgyay, V. W., Reynolds, J., \& Yeang, K. (2015). Design with Climate (REV-Revi). Princeton University Press. https://doi.org/10.2307/j.ctvc77kqb

Paramita, B., \& Fukuda, H. (2013). Study on the Affect of Aspect Building Form and Layout Case Study: Honjo Nishi Danchi, Yahatanishi, Kitakyushu- 
Fukuoka. Procedia Environmental Sciences, 17, 767774. https://doi.org/10.1016/j.proenv.2013.02.094

Parkinson, T., \& de Dear, R. (2017). Thermal pleasure in built environments: spatial alliesthesia from air movement. Building Research and Information, 45(3), 320-335. https://doi.org/10.1080/09613218.20 $\underline{16.1140932}$

Ramadhan, T., Wijaya, K., Muttaqin, Z. R., \& Rahmat, A. (2018). Sustainable Streetscape pada Koridor Kawasan Komersial. Jurnal Arsitektur ARCADE, 2(1), 24-32.

Salata, F., Golasi, I., de Lieto Vollaro, R., \& de Lieto Vollaro, A. (2016). Urban microclimate and outdoor thermal comfort. A proper procedure to fit ENVImet simulation outputs to experimental data. Sustainable Cities and Society, 26, 318-343. https://doi. org/10.1016/j.scs.2016.07.005

Stewart, R. H. (2004). Introduction to Physical Oceanography. Texas A\&M University. Retrieved from https://books.google.co.id/ books?id=Cq4PAQAAIAAI

Sujatmiko, W., Rahmat, A., \& WIjaya, K. (2019). Analysis Of Data Climate The Several Town In Indonesia For Support The Development Of Standard Adaptive Comfort The Traditional Homes. Wahyu. Indonesian Journal of Built Environmental \& Sustainability, 1(1), 73-77.

Syafrina, A., Koerniawan, M. D., Novianto, D., \& Fukuda, H. (2020). Influence of Urban Water Body on Thermal Environment in Pontianak City. Journal of Asian Institute of Low Carbon Design, 163-166.

Taleghani, M., Kleerekoper, L., Tenpierik, M., \& Van Den Dobbelsteen, A. (2015). Outdoor thermal com- fort within five different urban forms in the Netherlands. Building and Environment, 83, 65-78. https://doi.org/10.1016/j.buildenv.2014.03.014

Wang, L., Tian, Y., Kim, J., \& Yin, H. (2019). The key local segments of human body for personalized heating and cooling. Journal of Thermal Biology, 81(19), 118-127. https://doi.org/10.1016/j.jtherbio.2019.02.013

Wonorahardjo, S. (2012). New Concepts in Districts Planning, Based on Heat Island Investigation. Procedia - Social and Behavioral Sciences, 36, 235-242. https://doi.org/10.1016/j.sbspro.2012.03.026

Xi, T., Li, Q., Mochida, A., \& Meng, Q. (2012). Study on the outdoor thermal environment and thermal comfort around campus clusters in subtropical urban areas. Building and Environment, 52, 162-170. https://doi.org/10.1016/j.buildenv.2011.11.006

Yin, H., Wang, L., Yang, J., \& Chen, M. (2020). Local thermal responses of male college students of three thermal preference groups. Energy and Buildings, 228, 110497. https://doi.org/10.1016/j.enbuild.2020.110497

Zheng, S., Guldmann, J.-M., Liu, Z., \& Zhao, L. (2018). Influence of trees on the outdoor thermal environment in subtropical areas: An experimental study in Guangzhou, China. Sustainable Cities and Society, 42, 482-497. https://doi.org/10.1016/j. scs.2018.07.025

Zomorodian, Z. S., Tahsildoost, M., \& Hafezi, M. (2016). Thermal comfort in educational buildings: A review article. Renewable and Sustainable Energy Reviews, 59, 895-906. https://doi.org/10.1016/j. $\underline{\text { rser.2016.01.033 }}$ 